BEYON D

THE

WHITENESS

OF

WHITENES S 



\section{BEYOND THE WHITENESS}

\section{OF WHITENESS}

Memoir of a White Mother of Black Sons

TWENTIETH ANNIVERSARY EDITION WITH NEW PREFACE

Jane Lazarre

DUKE UNIVERSITY PRESS Durham and London 2016 
(C) 1996 Duke University Press

Preface (C) 2016 Jane Lazarre

Cover design by Martyn Schmoll

All rights reserved

Printed in the United States of America

on acid-free paper $\infty$

Library of Congress Cataloging-in-Publication Data

Names: Lazarre, Jane, author.

Title: Beyond the whiteness of whiteness :

memoir of a white mother of black sons / Jane Lazarre.

Description: Twentieth anniversary edition. |

Durham : Duke University Press, 2016.

Includes bibliographical references and index.

Identifiers: LCCN 2015039455

ISBN 9780822361473 (hardcover : alk. paper)

ISBN 9780822361664 (pbk. : alk. paper)

ISBN 9780822374I45 (e-book)

Subjects: LCSH: Mothers and sons-United States. |

Racially mixed children-United States.

Classification: LCC HQ755.85.L39 2OI6 | DDC 306.874/3-dc23

LC record available at http://lccn.loc.gov/20I5039455 
For Douglas H. White and

Lois Meadows-White and for

Leona Ruggiero, who has been with me every step of the way. And for

Simeon Meadows White, in lasting memory. 
